\title{
Beginning BASIC
}

\author{
P. E. Gosling, B.Sc., A.F.I.M.A.
}

Second Edition 
All rights reserved. No part of this publication may be reproduced or transmitted, in any form or by any means, without permission.

First edition 1977

Reprinted 1979, 1981

Second edition 1982

Published by

THE MACMILLAN PRESS LTD

London and Basingstoke

Companies and representatives

throughout the world

Typeset in 10/12 IBM Press Roman by RDL., 26 Mulgrave Road, Sutton, Surrey

ISBN 978-0-333-33336-5

ISBN 978-1-349-16837-8 (eBook)

DOI 10.1007/978-1-349-16837-8

The paperback edition of this book is sold subject to the condition that it shall not, by way of trade or otherwise, be lent, resold, hired out, or otherwise circulated without the publisher's prior consent in any form of binding or cover other than that in which it is published and without a similar condition including this condition being imposed on the subsequent purchaser. 


\section{Contents}

Preface v v

1. What is a Computer? 1

2. Talking to a Computer 11

3. Introduction to BASIC 18

4. Teleprinter Algebra 31

$\begin{array}{lll}\text { 5. Printing Literals } & 36\end{array}$

6. Conditional and Unconditional Jumps 40

7. Commas and Semicolons 47

8. FOR ... NEXT ... Loops 53

9. Lists and Arrays 62

$\begin{array}{ll}\text { 10. Function Statements } & 76\end{array}$

$\begin{array}{ll}\text { 11. REM Statements } & 80\end{array}$

12. Saving and Deleting Programs 82

13. Using the Paper-tape Punch and Reader 85

14. Specimen Programs $\quad 88$

$\begin{array}{ll}\text { Summary of BASIC } & 99\end{array}$

$\begin{array}{ll}\text { Index } & 105\end{array}$ 


\section{Preface}

The purpose of this book is to introduce a computer language known as BASIC to what are usually termed 'first-time users'. First-time users may be school children using a computer terminal as part of C.S.E. and G.C.E. courses, technical college students, university undergraduates and commercial and industrial users.

Now that computer terminals are becoming a greater and greater part of everyday life there will be many people who, at some time or another, will have to sit at a terminal and suffer the rather peculiar sensation of having a typewriter which talks back at them. It is just for such people that this book has been written. It attempts to give an insight, in simple terms, into what is going on inside the computer and how to make it your servant rather than your master.

It is a popular fallacy that you have to be clever at mathematics to write computer programs. All that is required is a logical approach to a problem and the ability to obey certain simple rules. These rules are carefully set out and in the numerous illustrative examples the effects of obeying, and not obeying, them are shown.

To the non-expert the majority of computer manuals on BASIC and many of the books on the subject tend to go too far, too fast and lose the reader in a welter of useful but seemingly irrelevant information. What has been attempted here is to proceed a step at a time and introduce the various BASIC instructions and commands as they are required, to produce better and more sophisticated programs.

The particular 'dialect' of BASIC used in this book is that offered by Data General Limited on their NOVA and ECLIPSE lines of computers and all the programs written in this book are in Revision 4 of Data General BASIC.

Acknowledgement is made to Data General Limited and Teleprinter Equipment Limited. Many thanks go to D. J. Billings, for photographs taken of equipment in the Peterborough Technical College Computer Centre. My grateful thanks is also extended to the Vice-Principal of Peterborough Technical College for permission to use the College's NOVA computer to provide the printout of the programs used as examples in this book.

Lastly much thanks must be given to my wife for the unenviable task of typing a coherent copy of my attempts at compiling the manuscript.

The world of computers is moving so fast that many things written about them are out of date by the time of publication. This book is no exception. Since the first edition was published in 1977 microcomputers have proliferated and the 
Government has announced its intention that there should be at least one of these machines in every secondary school as quickly as possible. Hence the first two chapters of this book have been brought up to date acknowledging the fact that what was originally written in those chapters needed to be expanded to cover the rapid growth of the availability of cheap computing.

\section{P. E. GOSLING}

